\title{
MYTHS AND LEGENDS OF THE BLACK SEA REGION
}

\author{
(C) Yulia A. Petrova, Yulia S. Shevkun \\ Rostov State University of Economics, Rostov-on-Don, Russian Federation \\ science-almanac@mail.ru
}

The first ideas of the Greeks about the Black Sea region and about the peoples, who inhabited it, had been formed long before the colonization thanks to the travelers and traders. The sea was rich in fish, and the coastal lands were rich in shipborne and construction timber, and in ironstone. But sailing in the Black sea was dangerous for seamen. Because of the weak indentation of the coasts there were few convenient places for the harbors, there were almost no islands and peninsulas, so habitual for the Mediterranean Greeks. For a long time, the Northern borders remained unexplored. The sea, which was called "Póntos" by the Greeks, was considered to be a part of the Ocean, which surrounded the inhabited land by the bay. In the Ocean, according to the ancient ideas, was the entrance to the kingdom of the dead, so sailing on it was equal to the trip to the Hades. In the same place, in the Ocean, where chaos reigned, it was possible to meet the "blessed islands", where the souls of the heroes lived. Such ideas, as well as the difficulties of navigation had been preventing the development of the shores of the Black Sea for a long time and had affected the very name of the sea, the

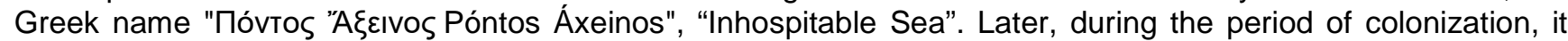
would be called "Eüそ̌ıvos Пóvtos Eúxeinos Póntos", "Hospitable Sea". The information about the Black Sea coast, colored by fiction, has been preserved in myths, legends and poems.

Key words: Black Sea Region, myths, legends, ancient historians, the Republic of Crimea.

\section{[Ю.А. Петрова, Ю.С. Шевкун Мифы и легенды Черноморского региона]}

Первые представления греков о Причерноморье и о народах, его населявших, сложились задолго до колонизации благодаря путешественникам и торговцам. Море было богато рыбой, а прибрежные земли - корабельным и строительным лесом, железной рудой. Но плавание по Черному морю представляло опасность для мореплавателей. Из-за слабой изрезанности берегов имелось мало удобных мест для гаваней, почти не было островов и полуостровов, так привычных для средиземноморских греков. Долгое время северные границы оставались неизведанными. Море, которое греки называли Понт, считалось частью Океана, окружавшего обитаемую землю, его заливом. В Океане, по древним представлениям, находился вход в царство мертвых, поэтому плавание по нему приравнивалось к путешествию в Аид. Там же, в Океане, где царил хаос, можно было встретить «острова блаженных», на которых обитали души героев. Подобные представления, а также трудности мореплавания долгое время сдерживали освоение берегов Черного моря и отразились на самом наименовании моря - Понт Аксинский - море негостеприимное. Позже, в период колонизации, его назовут Эвксинским - «гостеприимным». Многочисленные сведения о Причерноморье, зачастую окрашенные вымыслом, сохранились в мифрах, сказаниях и поэмах.

Ключевые слова: Причерноморье, мифы, легенды, древние историки, Крымская республика.

Yulia A. Petrova - candidate of philosophical sciences, associate professor of foreign languages for economic specialties, Rostov state university of economics. Rostov-on-Don, Russian Federation.

Yulia S. Shevkun - student. Rostov state university of economics. Rostov-on-Don, Russian Federation.

Петрова Юлия Андреевна - кандидат фрилософрских наук, доцент кафредры иностранных языков для экономических специальностей. Ростовский государственный экономический университет. г. Ростов-на-Дону, Российская Федерация.

Шевкун Юлия Сергеевна - студентка. Ростовский государственный экономический университет. ฉ. Ростов-на-Дону, Российская Федерация.

In the legends and myths of Ancient Greece, far and unknown, in which the great heroes and even Olympic Gods were frequent guests, "Taurida" written by Homer, who was a 
famous author of the Iliad and the Odyssey was of considerable importance, full of dangers. Then, in the VIII century BC, for the ancient Greeks the whole area behind the Bosphorus, this "Terra incognito" was the limit of the well-known Oecumene, the entrance to the Kingdom of Hades [3].

According to the ancient Greek legends, the princess lo, beloved by the main Olympic god Zeus, was turned into a cow that was wandering in the search of refuge on the territory of the modern Republic of Crimea. Pursued by the huge gadfly, the fugitive in despair had swum across the modern Kerch Strait, which the Hellenes began to call the Cimmerian Bosphorus, the "cow ford". As for mere mortals, only the bravest sailors went to the patrimony of the ancient God Pontus in the search of fame and fortune. However, the complexity of navigation, the lack of convenient bays, strong storms and militant Aborigines had been a deterrent to the settlement of these places by the Greeks for a long time. Travelers' stories gave rise to the legends about the "Inhospitable Sea", which smashed and drowned ships, about huge eagles and gryphons that attacked the Hellenes from the air, and about the treacherous mountaineers who were waiting for galleys of the unfortunate in quiet bays, and after killing them on their altar the bloodthirsty goddess. Impressed by such narratives, popular rumor immediately settled in these parts the most dismal representatives of their pantheon. Thus, the ancient historian Diodorus of Sicily narrates that in those days Taurida was ruled by the insidious goddess of witchcraft and darkness of Hecate, who had poisoned her fierce father Perses, the son of the sun god Helios, to obtain power. It was she who had erected the sanctuary on the rocky shore of the sea, in which they sacrificed all the strangers sailing to her country. The ancients also called her the mother of two great sorceresses, Kirk (Circe) and Medea, who became the heroines of certain myths. The period of the great Greek colonization contributed to the active development of the lands of Taurida and the emergence of many settlements of the ancient Hellenes. Cruises by the ships became safer, and the Black Sea was renamed hospitable. Mythology has changed. The place of the dark gods was occupied by the Olympians [2]. Thus, the story appeared, according to which the god of winemaking Dionysus gave the name of this mountain region when traveling around the world. When he arrived at the peninsula, he decided to teach people about farming and viticulture, and therefore he harnessed a couple of bulls for this business personally. These very sacred animals (in Greek, "Tavros" means "bull") served as the basis for the name of the country and the tribe inhabiting it.

As for the local Tavra goddess Deva, she was identified by the Greeks with Artemis Tavropolya, herding bulls. There is a legend telling even about inviting her to Olympus, where she agreed to patronize the Hellenes who settled in Tavrika. Proof of this kind of alliance can serve as numerous archaeological finds of images of the Virgin in the territory of Chersonese. But the main evidence is the ruins of the temple in her honor, as well as the marble slab with the oath of the citizens of this policy, which begins with the words: "By Zeus, Gaia, Helios, the Virgin, the gods and goddesses of the Olympic ..." Union of the Celestials, which became the personification of the partial unity of the Taurus and Hellenic cultures, finally symbolized the entry of the Crimea into the borders of the Greek civilization. The search for the legendary temple of the goddess of the Taurians had been conducted by archaeologists, historians and travelers for over three centuries [7]. Among the alleged places its location is often called Cape Fiolent or its environs, as well as the territory of the village Partenit in the region of Mount Ayu-Dag. Even the great poet Pushkin, while visiting Fiolent, left his opinion in the verse: "Why does cold doubt? I believe there was a formidable temple here, where the blood of thirsty gods smoked sacrifices..." [2]. However, many modern scholars are inclined to think that there were no temples with huge columns and forty steps, as the ancient authors described their cultures. The real sanctuary of Leva was most likely a simple altar on a steep cliff [1]. 
One of the most famous natives of the Crimea was Achilles (Achilles). The Byzantine historian Lev Deacon mentions that, according to the legend, this hero of the Trojan War was a Scythian, originally from the Bospor town of Mirmikon (Mirmekia), which stood on the site of the modern Cape Quarantine (Kerch). However, he was expelled for his stupidity, ferocity and arrogance of spirit, and then he settled in the north-east of Greece in Thessaly. Visual author of the Achilles Scythian origin, this author also cuts his cloak, fastened with a clasp, blond hair, light blue eyes, crazy irritability and cruelty.

The legendary hero of ancient Greek myths Hercules was noted in the Crimea with his exploits. In the minds of the Greek settlers of the Northern Black Sea region, this mighty son of Zeus was not only the greatest hero, but also the patron. The reason for such worship again became the legends about the numerous visits of the strongman of these lands. For the first time Hercules visited the peninsula as a member of the crew of Yasonovo Argo, and later became a frequent guest here. He was credited with driving all the monsters and monsters from the shores of Ponta, defeating the warlike Amazons of the Meotids (Sea of Azov), led by their queen Hippolyte and other glorious deeds. But the main thing the Hellenes associated with the presence of this demigod in these places is the appearance of the whole people, the Scythians. According to Herodotus, this happened when Hercules was collecting runaway cows of the defeated giant Garyon [5]. In his search, he drove to the limits of the Tauride Peninsula, where he decided to rest. But when he awoke, he noticed the loss of his chariot and horses. Bypassing the neighborhood, he met an amazing woman, whose body ended in a serpent's tail. She confessed to the theft, but promised to return the property to the hero only after her children would have been born from Hercules. So, three brothers were born, from one of which all the Scythian kings led their ancestry. These legends are reflected in art. In the museums of the Crimea, one can find the images of Hercules resting and fighting, found by archaeologists, as well as the sculptures and figurines of the Scythian snake-like mother goddess Api.

But the most famous mythical plot, which actions took place in the Crimea in ancient times, is perhaps the legend of the priestess Iphigenia. The great ancient Greek playwright Euripides dedicated a separate theatrical tragedy to her. The plot of her story tells how the king of Argos Agamemnon, going on a campaign against Troy, at the request of the gods decides to sacrifice his own daughter Iphigenia. But the goddess Artemis at the last moment saves the girl, taking her to distant Tavrida, where she becomes a priestess in the temple of fierce Tauris. After many years, the brother of Iphigenia Orestes and his comrade Pilad landed off the coast of the peninsula, and the Delphic oracle gave them the task of returning Artemis's wooden idol to Hellas. However, during the search the friends fall into the hands of the Highlanders, and those, according to their custom, are preparing to sacrifice them. Iphigenia, who was supposed to hold this terrible rite, recognizes her brother and, having deceived the king of the Tauristaurus, leaves the peninsula together with the captives, taking with her the sacred image. It is worth noting that the names of the heroes of the ancient Greek tragedy are preserved in the modern Crimean toponymy. Thus, in one of the Fiolent coves, two small rocks protrude from the water, named after the friends, Orest and Pilad.

The next part will be about the Crimean adventures of Odyssey. In the XIX century it was started to talk about the fact that the ingenious husband of Penelope could travel not only in the Mediterranean, but also the Black Sea. Among the apologists of this version were such scholars as the geographer K. Ritter, the geologist D. de Monpere, the historian A. Ashik, the natural scientist K. Baer, the historian of literature and the archaeologist G. Karaulov [6]. In their writings they pointed out that the tenth, the eleventh and the twelfth songs of Homer's poem could well have taken place on the Black Sea. But the main Crimean episode, many researchers now consider the collision of the flotilla of Odyssey with the tribe of cannibals lestrigonov, which occurred, apparently, in Balaklava Bay. It was here that the formida- 
ble giants, who are identified with the brands, destroyed 11 of the 12 Greek ships, and the surviving sailors "were strung on pins and taken to their town for food". The next fragment of the Odyssey, which could have happened in Tavrida or at its borders, can be considered the descent of the hero to Hades. So, one of the alleged entrances to the realm of the dead is called the Roaring Grotto of Karadag, which today amazes with its mystery, and the waves create there a unique sinister roar. Among the adherents of this version was the famous poet and artist Maximilian Voloshin, who specifically showed his guests "the gate to which Orpheus went after Eurydice." But the place where the Greeks meet with the terrible one-eyed Cyclops is popular rumor called Cape Megane [4], but this hypothesis exists only at the level of rumors. A bold version of the Crimean ethnographer Alexander Frolov can be distinguished from modern studies of the Black Sea wanderings of Tsar Ithaki. After studying the "Odyssey", he found out in the descriptions of the lair of Scylla and Charybdis the Gurzuf Bay, grottoes and rocks of Adalara. As evidence, the researcher cites the results of an underwater archaeological expedition, which discovered in this place the traces of numerous shipwrecks, caused by the strongest currents and pitfalls. Perhaps the ill fame of the rocky islands created the myth of the monsters that came to us thanks to Homer [1].

Summarizing all the above, the image of Tavrida in the mythology of the ancient Greeks underwent a kind of evolution from the forbidden land to the birthplace of the greatest heroes and the place of their exploits. It is also safe to say that the basis for the legends about the peninsula were very real historical events and facts, which are now confirmed by archaeologists and science. Thus, we can make a logical conclusion that the Greeks discovered for themselves and for the whole world a beautiful, but forgotten by the gods, region, turned it into a blooming garden, decorated it with works of their hands and soul.

\section{Лumepamypa}

1. Пасечников И. В краю героев и богов // Полуостров сокровищ. 2013. № 4.

2. Античная мифология и Причерноморье // Сборник рассказов. [Электронный ресурс]: http://www.anapacity.com/istoriya-krasnodarskogo-kraya/antichnaya-mifologiya-iprichernomore.html (дата обращения: 1.02.2019).

3. Интервью корреспондента газеты «Аргументы и Факты-Юг» Алины Меньковой со старшим научным сотрудником отдела археологических фондов музея имени Е.Д. Фелицына с Владиславом Улитиным. 2015.

4. Basilaia M.A., Zharkova M.G. Search for new ways of ecological crisis overcoming // Научный альманах стран Причерноморья. 2017. № 2.

5. Kolosova O.Y., Goncharov V.N. Positive ecological practices formation as condition for ecological crisis overcoming // Научный альманах стран Причерноморья. 2017. № 2.

6. Petrova Yu., Yarovoy M. Comparative-historical and cultural analysis of eastern. Black sea region people's interaction // Научный альманах стран Причерноморья. 2017. № 3 (11).

7. FilatovaT.V. Expedition hydrochemical studies of the Black Sea coastal zones and the Kerch Strait in 2007-2008 // Научный альманах стран Причерноморья. 2017. № 3.

\section{References}

1. Pasechnikov I. "V kraiu geroev i bogov", zhurnal "Poluostrov sokrovishch" nauchnaia stat'ia ["In the Land of Heroes and Gods", the journal "Treasury Peninsula"]. 2013. No 4. (in Russian). 
2. Antichnaia mifologiia i Prichernomor'e. Sbornik rasskazov [Ancient Mythology and Black Sea Coast, a collection of stories]. Available at: http://www.anapacity.com/istoriyakrasnodarskogo-kraya/antichnaya-mifologiya-i-prichernomore.html (in Russian).

3. Interv'iu korrespondenta gazety "Argumenty i Fakty-lug' Aliny Men'kovoi so starshim nauchnym sotrudnikom otdela arkheologicheskikh fondov muzeia imeni E.D. Felitsyna Vladislavom Ulitinym [An interview of the correspondent of the "Argumenty I Fakty-Yug" newspaper Alina Menkova with the senior research associate of department of archaeological funds of the museum of E.D. Felitsyna Vladyslav Ulitin]. 2015 (in Russian).

4. Basilaia M.A., Zharkova M.G. Search for new ways of ecological crisis overcoming. Scientific almanac of the countries of the Black Sea region. 2017. No 2.

5. Kolosova O.Y., Goncharov V.N. Positive ecological practices formation as condition for ecological crisis overcoming. Scientific almanac of the Black Sea countries. 2017. No 2.

6. Petrova Yu., Yarovoy M. Comparative-historical and cultural analysis of eastern Black sea region people's interaction. Scientific almanac of the Black Sea countries. 2017. No 3 (11).

7. FilatovaT.V. Expedition hydrochemical studies of the Black Sea coastal zones and the Kerch Strait in 2007-2008. Scientific almanac of the Black Sea countries. 2017. No 3. 